Article

\title{
Increasing Iron, Zinc, Calcium, Magnesium and Potassium Concentration and Their Bioavailability in Spring Wheat Mutant Lines for Improving Health
}

\author{
Saule Kenzhebayeva 1*, Gulina Doktyrbay 1, Alfia Abekova 3, Saule Atabayeva 1, Gulzira \\ Ernazarova ${ }^{1}$, Nargul Omirbekova ${ }^{1}$, Svetlana Turasheva ${ }^{1}$, Fatma Sarsu ${ }^{4}$ and Guoping Zhang ${ }^{2}$ \\ 1 Department of Biotechnology, Kazakh National University the named after al-Farabi, Almaty, Kazakhstan; \\ kenzhebaevas@mail.ru; KenzhebaevaS@kaznu.kz \\ 2 Agronomy Department, Zhejiang University, Zijinggang Campus, China; zhanggp@zju.edu.cn \\ $3 \quad$ Kazakh Institute of Agricultural and Breeding, Almaty region, Kazakhstan; aabekova@mail.ru \\ 4 The Plant Breeding and Genetics Section, Joint FAO/IAEA Division, International Atomic Energy Agency, \\ Vienna, Austria; F.Sarsu@iaea.org \\ * Correspondence: kenzhebaevas@mail.ru; KenzhebaevaS@kaznu.kz; Tel.: +07-727-2211201-
}

\begin{abstract}
Metal, primarily Fe and Zn, deficiencies affect over half of the world's population. Human diets with prevalent cereal products cause micronutrient malnutrition. Biofortification is one of the most effective approaches to alleviate malnutrition. Spring wheat genetically stable $(\mathrm{M} 7)$ mutant lines developed with 100 and 200 Gy gamma treatments to broaden genetic variation and search for new resources were analyzed for nutritionally important minerals $(\mathrm{Ca}, \mathrm{Mg}, \mathrm{K}, \mathrm{Fe}$, and $\mathrm{Zn}$ ), their bioavailability, and grain protein content (GPC). The variation was $172.3-883.0 \mathrm{mg} / \mathrm{kg}$ for Ca, $472.9-$ $1088 \mathrm{mg} / \mathrm{kg}$ for Mg, 3128.6-5487.5 mg/kg for K, 40.9-89.0 mg/kg for Fe, and 22.2-89.6 mg/kg for Zn. In mutant lines, among the investigated minerals, the highest increases in concentrations were observed in $\mathrm{Fe}, \mathrm{Zn}$, and Ca when compared to the parent. Some mutant lines, mostly in the $100 \mathrm{~Gy}-$ derived germplasm, had two to three times higher $\mathrm{Fe}, \mathrm{Zn}$, and $\mathrm{Ca}$ concentrations, lower phytic acid concentration (1.4-2.1 times), and 6.5-7\% higher GPC compare to the parent. Variation was detected for the Ca:Phy, Mg:Phy, Phy:K, Phy:Fe, and Phy:Zn molar ratios (1.27-10.41, 5.05-18.68, 1.66-4.87, $1.40-5.32$ and 1.78-11.78, respectively). The results showed how the genetic variation could be generated through radiation and be useful to develop biofortification by micronutrient varieties with their appropriate bioavailability to overcome malnutrition.
\end{abstract}

Keywords: bread wheat; correlations, gamma, grain nutrients concentrations; mutation, phytic acid; metals bioavailability

\section{Introduction}

Nutrient malnutrition represents one of the major challenges worldwide characterized by an increasing number of people with different forms of its manifestation [1-3]. Nearly $30 \%$ of humanity-infants, children, adolescents, adults, and older persons in the developing world-are currently suffering from one or more of the multiple forms of malnutrition [2]. Malnutrition and diet are by far the biggest risk factors for this global disease: every country is facing a serious public health challenge from malnutrition [3]. There are 49 known essential nutrients for sustaining human life [4]. Insufficient intake of even one of these nutrients resulting from diets can cause deleterious metabolic contraventions leading to diseases, reduction of human health and shortened life expectancy, the 
impairment of the quality of life cognitive functions, delayed development in children, and large economic costs to society [4,5]. Malnutrition, widely recognized as a major health problem, is especially caused by cereal-based diets that are primarily deficient in micronutrients ( $\mathrm{Zn}$ and Fe) and is predominant in low-income and middle-income countries [6]. The consequences of a majority of malnutrition and nutrition-related diseases including intrauterine growth, which is $23.8 \%$ of all births per year; protein-energy malnutrition (underweight) is in $26.7 \%$ of children under-five worldwide; and over $60 \%$ of the world's 6 billion people are Fe deficient and over $25 \%$ are $\mathrm{Zn}$ deficient [7].

In human nutrition, $\mathrm{Fe}$ and $\mathrm{Zn}$ are frequently evaluated together [8] as these minerals share common dietary sources, the consumption of both metals from food is enhanced and inhibited by similar compounds [5,9], and as a result, a deficiency of both nutrients is thought to occur simultaneously. In addition, calcium $(\mathrm{Ca})$, magnesium $(\mathrm{Mg})$, and copper $(\mathrm{Cu})$ deficiencies are common in many developed and developing countries [10-14].

The 22 developing countries listed are those whose populations receive $43-78 \%$ of dietary Fe and $56-88 \% \mathrm{Zn}$ from $\mathrm{C}_{3}$ grains and legumes [6]. Wheat (Triticum aestivum L.) is consumed as one of the major human foods with increasing demand due to growing population and as a source of essential nutrients and protein for nutrition [2]. Wheat provides $28 \%$ of the world's edible dry matter and up to $60 \%$ of the daily calorie intake in developing countries $[1,15,16]$. However, genetic gains in grain yield have not changed over the years or decreased wheat nutritional value, particularly in the Fe and Zn grain protein content [17-19]. Such a trend will worsen since as it has recently been shown that the edible portions of food crops grown in open field conditions under elevated atmospheric $\mathrm{CO}_{2}$ of 550 parts per million have significantly decreased iron contents by $4-10 \%$ [20]. In addition, over the years, wheat breeding has reduced genetic diversity through the replacement of cultivars by modern higher yielding varieties ${ }^{5}$, which can result in decreased nutritional quality. The increase in yield was accompanied by the dilution effect of micronutrient concentrations due to increased kernel weight [21].

Biofortification, i.e., the genetic enhancement of nutrient concentration in the grains of stable food crops through breeding, is one of the most cost-effective and environmentally safe ways to prevent and alleviate nutrient malnutrition in humans [4,22,23]. It was demonstrated, for example, under biofortified wheat in the diet, $\mathrm{Zn}$ human consumption was substantially higher relative to the non-biofortified one [24]. Moreover, the biofortification of crops through breeding has multiplicative advantages [22].

Along with increasing the concentration of nutrients in food crops, it is importance to reach a high bioavailability for human nutrition [25]. Wheat foods are rich in antinutrients, first of all, phytic acid (Phy), which interferes with the absorption or utilization of nutrients in humans [1,5]. In general, staple food crop grains contain very low bioavailable Fe and $\mathrm{Zn}$ (i.e., about $5 \%$ of the total grain Fe and about $25 \%$ of the total $\mathrm{Zn}$ are bioavailable). To increase the Fe bioavailability from 5 to $20 \%$, it would be equivalent to increasing the total Fe fourfold [26]. It has been noted that it is genetically much easier to significantly improve the bioavailability of Fe and $\mathrm{Zn}$ in comparison to increasing their total concentration by this magnitude based on conventional breeding [26,27]. To measure mineral bioavailability in the human diet, their molar ratio with Phy has been widely used [4]. The regulation of Fe status in the human body is carried out through absorption rather than secretion and at the same time, its $\mathrm{Zn}$ homeostasis in addition to absorption is also regulated through the gastrointestinal secretion and excretion of endogenous Zn [28]. 
Breeding for low Phy concentration is considered to be a reasonable objective to enhance the nutrient bioavailability of crops. For the decline of Phy, essential efforts have been made to mutagenize crops. Low phytate mutants (lpa) have been reported for several cereals using chemical and physical mutagenesis [29-33]. Sussessful breeding for associated increases in the nutritional value of cereal foods and yield-associated traits requires genetic variation, which has to be achieved without negative effects on valuable ones. The genetic diversity of crops has decreased primarily as a consequence of breeding, including the repeated use of local germplasm and the adoption of breeding schemes that do not favor genetic recombination [34]. Mutagenesis is a powerful instrument to broaden genetic variation and has been used for yield increase, but has been studied less for the improvement of grain nutritional value [35,36]. The FAO/IAEA Mutant Variety Database in 2014 reported 3220 worldwide mutant varieties of 214 plant species [37]. Mutagenesis is especially valuable for inducing novel genetic variations in major crops that have restricted genetic variability [35].

Macro elements such as $\mathrm{Ca}, \mathrm{Mg}$, and $\mathrm{K}$, etc. as abundant minerals in the body are the most important components required by humans in their daily food $[4,14,38]$. All body processes depend upon the action of minerals to activate diverse enzymes performing metabolic functions. An adult body contains approximately $140 \mathrm{~g} \mathrm{~K}$, the majority of which resides intracellularly with a small amount in extracellular fluid [39]; $25 \mathrm{~g} \mathrm{Mg}$ with $50 \%$ to $60 \%$ present in the bones and the rest mostly in the soft tissues [38]; and less than 1\% of total body calcium is needed to support these critical metabolic functions [40]. A low level of these essential nutrients have been linked to metabolic syndrome, insulin resistance, heart disease, hypertension, and some forms of cancer. The relationship between $\mathrm{Ca}$ and $\mathrm{Mg}$, adequacy of both $\mathrm{Ca}$ and $\mathrm{Mg}$ as well as the $\mathrm{Ca}: \mathrm{Mg}$ ratio are important for health [41]. Health consequences should be considered for the $64-67 \%$ of adults in the USA who do not meeting their $\mathrm{Mg}$ requirement from foods, many of whom also consume below their Ca requirements and their increasing Ca:Mg ratio from foods [42].

Human studies indicated that Phy inhibits Ca absorption, but its effect on Ca bioavailability seems to be less pronounced when compared to that on the bioavailability of Fe and particularly $\mathrm{Zn}$ [43]. This is possibly related to the relatively high Ca concentration of cereals foods, the capability of the bacterial flora in the colon to dephosphorylate Phy, and the intake of Ca from the colon [44]. Relatively few studies have described the effects of Phy on dietary Mg utilization. Phytate has been shown to decrease its bioavailability in in vivo studies, but it appears that the effect of phytate on $\mathrm{Mg}$ availability is less marked than those for some other essential elements [45].

The nutritional value of a crop is dependent on grain protein content (GPC) having a great impact on the end products [46]. Breeding for improvement of GPC is difficult due to a restriction of the range of GPC variation in cultivars.

The objectives of this study were (1) to evaluate the variability in $\mathrm{Ca}(\mathrm{CaC}), \mathrm{Mg}(\mathrm{MgC}), \mathrm{K}(\mathrm{KC})$, $\mathrm{Fe}(\mathrm{FeC}), \mathrm{Zn}(\mathrm{ZnC})$, and Phy (PhyC) concentrations, and grain protein content (GPC) in spring wheat grain of parent (cv. Zhenis), advanced mutant lines (M7) which are derived 100- and 200 Gy-gamma doses treatment; (2) to estimate the bioavailability of metallic nutrients, and (3) to evaluate the square correlation between thousand grain weight (TGW) and quality parameters. The comparison of mineral concentration in cv. Zhenis, 100, and 200 Gy-derived mutant lines with recommended uptake and percentage of recommended uptake from flour consumption was also determined. 


\section{Materials and Methods}

\subsection{Plant Material}

Grains of the spring bread wheat awn-less variety Zhenis (Triticum aestivum L.) were irradiated with 100 Gy and 200 Gy doses from a ${ }^{60}$ Co source at the Kazakh Nuclear Centre. After irradiation, seeds were planted to raise $\mathrm{M}_{1}$ plants [47]. The $\mathrm{M}_{1}$ generation was grown in the experimental field of the Kazakh Institute of Agricultural and Breeding near Almaty (43 $15^{\prime} \mathrm{N}, 76^{\circ} 54^{\prime} \mathrm{E}$, elevation $550 \mathrm{~m}$ above mean sea level). Single spikes from each plant for the $\mathrm{M}_{2}$ generation were harvested, and selection of the best lines based on the yield of individual plants continued to the M7 generation. Seed was gathered from the main spike; although tiller number and size varied, each plant produced only a single main spike. Seeds from the best yielding mutant lines were individually selected in each generation. The selection criteria for these lines were grain weight per main spike (GWS) and per plant (GWP) and applied in the $\mathrm{M}_{3}$ and $\mathrm{M}_{4}$ generations (2011 and 2012) based on the values for the parent cv. Zhenis grown in the same trial conditions. In 2011, the parent line had mean GWS of 1.20 $\pm 0.51 \mathrm{~g}$ and GWP of $1.85 \pm 0.61 \mathrm{~g}$. The threshold criteria for selection in the $\mathrm{M}_{4}$ generation were GWS $>1.4 \mathrm{~g}$ and GWP > $2.3 \mathrm{~g}$ for the mutant lines. The initial number of lines in the $\mathrm{M}_{1}$ generation was 2000 each for the $100 \mathrm{~Gy}$ and $200 \mathrm{~Gy}$ radiation doses. In the M3 generation, 61 lines (20\%) were selected from the $100 \mathrm{~Gy}$ irradiation dose population and 48 lines (16\%) were selected from the 200 Gy dose. The same numbers of lines for each radiation dose were selected for the $\mathrm{M}_{4}-\mathrm{M}_{6}$ generation. After harvesting the M7 plants, 23 lines and 8 lines from the original 100 and 200 Gy-treated germplasm were selected. The 100 Gy lines were numbered as follows: 6(9), 10(15), 11(6), 13(9), 15(1), 16(4), 17(7), 18(2), 20(10), 24(7), 26(5), 29(8), 36(13), 37(4), 39(2), 42(4), 43(43), 45(1), 47(2), 49(2), 52(10), 53(5), and 55(10); and 200 Gy lines were numbered: 57(4), 58(8), 59(2), 61(2), 62(2), 63(2), 64(2), and 65(3). These mutant lines, selected from the two different levels of irradiation doses, were then used for further analysis for nutritional qulaity. Grain samples from each mutant line and parent Zhenis were planted together in a field trial and were grown in three replicates of three row plots, $2 \mathrm{~m}$ long $\times 1.20 \mathrm{~m}$ width, and $20 \mathrm{~cm}$ between rows with 30 seeds planted per row for further evaluation. The trial was managed according to locally recommended agronomic practices. Applied fertilizers, time of their use, and soil were described [47]. Ten randomly selected lines were taken for analysis (five samples per row). To record yield associated traits, thousand grain weight (TGW) were measured as the mean weight of three sets of 100 grains per line multiplied by 10 .

\subsection{Determination of Grain Protein Content}

Grain protein content was determined with near-infra red reflectance (NIR) spectroscopy on whole grains (ZX50 Portable Grain Analyzer, USA) using proprietary calibration software provided (Zeltex Hagerstown, Ma USA). Three repetitions were done using 25 grains per line.

\subsection{Analysis of Grain Iron and Zinc Concentrations}

Grain samples (advanced M7 mutant lines and parent, cv. Zhenis) were washed with sodium dodecyl sulfate $(0.1 \%)$, rinsed in deionized water, dried to a constant weight at $65-70{ }^{\circ} \mathrm{C}$, and then ground with a mixer mill (Retsch MM400 GmbH). The digestion and extraction of the sample $(0.2 \mathrm{~g})$ are described in [47]. Magnesium $(\mathrm{MgC})$, calcium $(\mathrm{CaC})$, potassium $(\mathrm{KC})$, iron $(\mathrm{FeC})$, and zinc $(\mathrm{ZnC})$ 
concentrations were measured using flame atomic absorption spectroscopies Model NovAA350, AnalytikJena, Jena, Germany). Measurements of all minerals were checked against the certified reference values from the state standard samples LLC "HromLab", K-7473-98, Ca-7475-98, Mg-719095, Fe-7254-96, and $\mathrm{Zn}-7256-96$ diluted by $0.3 \% \mathrm{HNO}_{3}$. Three extract and analysis repetitions were performed.

\subsection{Phytic Acid Extraction and Determination, and Molar Ratios of Phy:Metals and Metals:Phy}

The extraction of Phy from the milled grain samples $(0.3 \mathrm{~g})$ was performed as described in [48] and $2.5 \mathrm{~mL}$ of the supernatant was treated with $2 \mathrm{~mL} 0.2 \% \mathrm{FeCl}_{3}$, and the mixture was boiled for 30 min with further centrifugation after cooling. The residue was washed twice with deionized water. A total of $1.5 \mathrm{M} \mathrm{NaOH}$ was added to the precipitation, shaken, and the solution centrifuged. Three $\mathrm{mL}$ of $0.5 \mathrm{M} \mathrm{HCl}$ was added to the precipitation, then shaken until the precipitation dissolved. The solution was diluted to $25 \mathrm{~mL}$ to measure Fe remaining in the solution by atomic absorption spectrophotometer (AAS, Shimadzu AA6300, Japan). Phy sodium (Sigma St Louis, Missouri, USA) was used to test the Phy recovery rate. The Phy test results suggested that the recoveries were between 96 and 102\%. The determination of Phy was based on the precipitation of ferric phytate and measurement of Fe remaining in the supernatant. The grain Phy was calculated by multiplying Fe content by a factor of 4.2. To calculate the molar ratios of Ca:Phy and Mg:Phy and Phy:K, Fe and Zn, the concentrations of Phy and the metals were converted into moles by dividing by their respective molar masses and atomic weights. The [Ca][Phy]/[Zn] (mol/kg) was also calculated.

\subsection{Statistical Analysis}

One-way ANOVAs were used for comparisons; all data were evaluated in R 3.0.2 (R Core Development Team 2013). Simultaneous tests of general linear hypotheses and Dunnett's contrasts were used for multiple comparisons of the means. Summary data are reported as mean values \pm standard deviations. Square correlation coefficients between TGW and grain quality parameters and $p$ values were calculated using GenStat software (10 th edition). A $p$-value of less than 0.05 was considered statistically significant.

\section{Results}

3.1. Variability in $\mathrm{Ca}, \mathrm{K}, \mathrm{Mg}, \mathrm{Fe}$ and $\mathrm{Zn}$ Concentrations in Grain of Spring Wheat M7 Mutant Lines and Parent

Significant differences in $\mathrm{Ca}, \mathrm{Fe}, \mathrm{Zn}, \mathrm{K}$, and $\mathrm{Mg}$ concentrations were found among the new spring wheat M7mutant lines developed using dose radiation of $100 \mathrm{~Gy}$ and $200 \mathrm{~Gy}$ and parent $\mathrm{cv}$. Zhenis. Table 1 shows the means and ranges of the parameters. The CaC varied from $172.3-883.0 \mathrm{mg} / \mathrm{kg}$ in mutant lines $(\mathrm{n}=93)$. Significantly enhanced $\mathrm{CaC}$ exceeded the parent by 1.23 to 2.47 times with its highest mean in 100 Gy-treated lines identified in $15 \mathrm{M} 7$ lines (48.4\%).
Table 1.
cv. Zhenis
100 Gy-lines
200 Gy-lines

Comparison

between trait

means and 


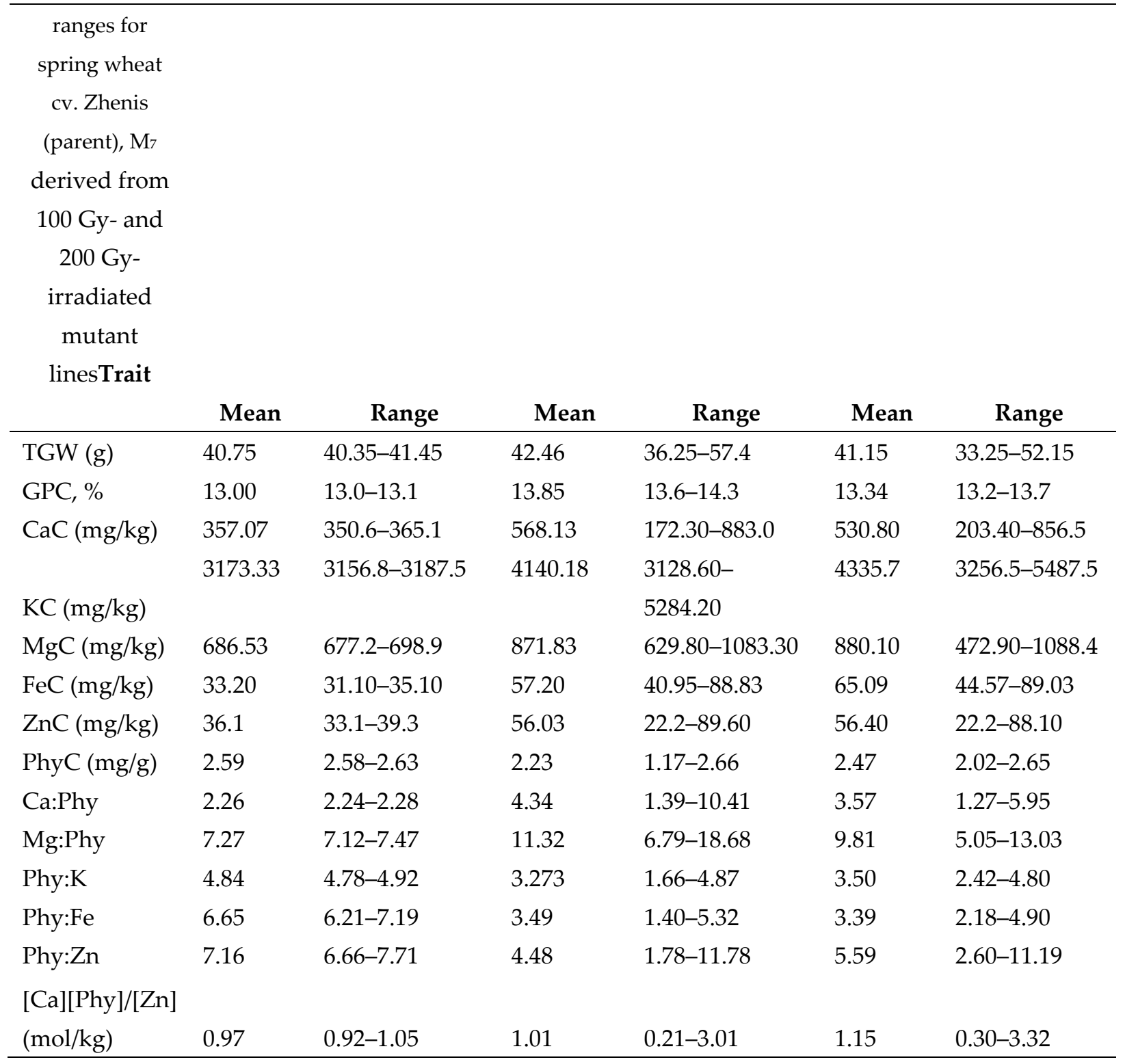

The KC ranged from $3128.6-5487.5 \mathrm{mg} \mathrm{kg}^{-1}$ with a mean $4190.6 \pm 680.7$. The four genotypes (12.9\%) had significantly 1.65 to 1.73 times higher $\mathrm{KC}$ than the parent. Variation for $\mathrm{Mg}$ was $472.9-$ $1088 \mathrm{mg} / \mathrm{kg}$ with $877.9 \pm 128.4$. In 27 lines (87.1\%), significantly higher MgC relative to the parent by 1.14 to 1.56 times was revealed. Significant variation was also found for the microelements, Fe and $\mathrm{Zn}$, between mutant lines which were derived 100 and 200 Gy-irradiated lines with means of 40.95$89.03 \mathrm{mg} / \mathrm{kg}$ and $22.2-89.6 \mathrm{mg} / \mathrm{kg}(\mathrm{n}=93)$, respectively. Significantly higher $\mathrm{FeC}$ and $\mathrm{ZnC}$ than the parent by 1.23 to 2.66 times and 1.45-2.42, respectively, were identified in $16(51.6 \%)$ and 17 (54.8\%) $\mathrm{M}_{7}$ lines. The GPC varied from 13.1 to $14.3 \%$ with a mean of $13.72 \pm 0.26 \%(n=93)$. The 17 genotypes (54.8\%), all of the 100 Gy-dosed lines, had a significantly 6.5 to $7.6 \%$ higher GPC relative to the parent. The mutant lines exhibited wide variations in PhyC from 1.17 to $2.66 \mathrm{mg} / \mathrm{g}$ (Table 1). When compared to the parent, significantly lower PAC by 1.25 to 2.02 times was detected in nine mutant lines (29\%).

Analysis of variance (ANOVA) with differences in all nutrient concentrations among cv. Zhenis and mutant lines are shown in Table 2. These results revealed significant differences between the $\mathrm{cv}$. 
Zhenis and derived $100 \mathrm{~Gy}$ - and $200 \mathrm{~Gy}$-mutant lines for all traits except that of Phy:Zn for cv. Zhenis and the 200 Gy-treated lines (Table 2). However, the interactions between the $100 \mathrm{~Gy}$ - and $200 \mathrm{~Gy}$ dosed lines were significant in terms of nutrient concentrations of FeC, GPC, and PhyC. For metals bioavailability, such associations were in the Ca:Phy and Mg:Phy molar rations. The radiation effect of 100 Gy was highest in GPC, indicating its increased efficiency to generate mutations in the genome associated with this trait. Traits such as $\mathrm{KC}$ and $\mathrm{FeC}$, and therefore in Phy: $\mathrm{K}$ and Phy:Fe, explained that greater variation of 200 Gy than 100 Gy treatment showed the most influence for their improvement under a high level of radiation.

Significant variations in the molar rations of Phy:metals (Ca, Mg, K, Fe and $\mathrm{Zn}$ ) were also noted between the parent and mutant lines (Table 2). Variation was detected for the Ca:Phy, Mg :Phy, Phy:K, Phy:Fe, and Phy:Zn molar ratios, (1.27-10.41, 5.05-18.68, 1.66-4.87, 1.40-5.32 and 1.78-11.78, respectively) (Table 1). The most noticeable variation in metal bioavailability between the parent and mutant lines was found for the Phy:Fe molar ratios, followed by Ca:Phy and Phy:Zn. The lowest means of these characteristics and therefore their highest bioavailabilities presented in the 100-Gyderived mutant lines were in intervals of 4.02-4.75 fold lower. It was also observed that the $100 \mathrm{~Gy}-$ treated lines significantly differed from the ones developed by the 200 Gy treatment in the Ca:Phy and Mg :Phy molar ratios (Table 2).

Table 2. Comparion of $\mathrm{Ca}, \mathrm{Mg}, \mathrm{K}, \mathrm{Fe}, \mathrm{Zn}$, and phytic acid concentrations and Phy:nutrients molar rations of advanced M7 mutant lines and parent grain of spring wheat cv. Zhenis (ANOVA analysis).

\begin{tabular}{|c|c|c|c|c|c|c|c|c|c|c|c|c|c|}
\hline $\begin{array}{l}\text { Sou } \\
\text { rce } \\
\text { of } \\
\text { vari } \\
\text { atio } \\
\text { n }\end{array}$ & Df & $\mathrm{CaC}$ & $\mathrm{MgC}$ & KC & $\mathrm{FeC}$ & $\mathrm{ZnC}$ & GPC & $\begin{array}{l}\text { Phy } \\
\text { C }\end{array}$ & $\begin{array}{l}\text { Ca: } \\
\text { Phy }\end{array}$ & $\begin{array}{l}\text { Mg:P } \\
\text { hy }\end{array}$ & $\begin{array}{l}\text { Phy: } \\
\text { K }\end{array}$ & $\begin{array}{l}\text { Phy } \\
\text { Fe }\end{array}$ & $\begin{array}{l}\text { Phy: } \\
\text { Zn }\end{array}$ \\
\hline $\begin{array}{l}\text { cv. } \\
\text { Zhe } \\
\text { nis } x \\
100 \\
\text { Gy- } \\
\text { dose } \\
\text { d } \\
\text { lines }\end{array}$ & 83 & $\begin{array}{l}23.1 \\
3^{* * *}\end{array}$ & $\begin{array}{l}58.3 \\
3^{* * *}\end{array}$ & $\begin{array}{l}44.75 \\
* * *\end{array}$ & $\begin{array}{l}64.97^{*} \\
* *\end{array}$ & $\begin{array}{l}21.87 \\
* * *\end{array}$ & $\begin{array}{l}647.78 \\
* * *\end{array}$ & $\begin{array}{l}16.20 \\
* * *\end{array}$ & $\begin{array}{l}27.18^{*} \\
* *\end{array}$ & $41.80^{* * *}$ & $\begin{array}{l}84.32^{*} \\
* *\end{array}$ & $\begin{array}{l}169.05 \\
* * *\end{array}$ & $\begin{array}{l}29.50 \\
* * *\end{array}$ \\
\hline $\begin{array}{l}\text { cv. } \\
\text { Zhe } \\
\text { nis } \\
x \\
200 \\
\text { Gy- } \\
\text { dose } \\
\text { d } \\
\text { lines }\end{array}$ & 38 & $\begin{array}{l}28.8 \\
9^{* * *}\end{array}$ & $\begin{array}{l}46.4 \\
5^{* * *}\end{array}$ & $\begin{array}{l}76.93 \\
* * *\end{array}$ & $\begin{array}{l}203.83 \\
* * *\end{array}$ & $\begin{array}{l}26.98 \\
* * *\end{array}$ & $\begin{array}{l}149.29 \\
* * *\end{array}$ & $\begin{array}{l}19.62 \\
* \quad\end{array}$ & $\begin{array}{l}36.50^{*} \\
* *\end{array}$ & $51.27^{* *}$ & $\begin{array}{l}134.82 \\
* * *\end{array}$ & $\begin{array}{l}468.55 \\
* * *\end{array}$ & 10.08 \\
\hline
\end{tabular}




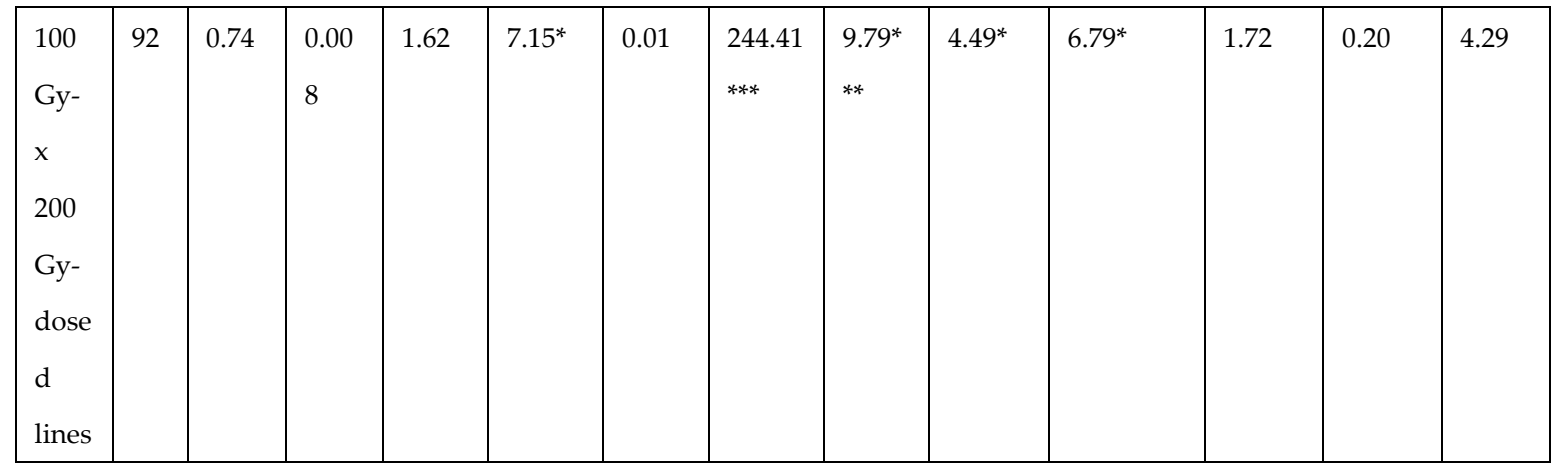

The lines were significantly different from the parent line. Each line was analyzed by three replicates. ${ }^{*}{ }^{* *}$, and *** denote significance at the $0.05,0.01$, and 0.001 probability level, respectively.

\subsection{Correlations between Nutrient Concentration, Phytic Acid and Thousand-Gain Weight}

To examine the relations among the macro- and microelement concentrations with phytic acid and yield, R squared correlation analysis was conducted (Table 3). In the parent, several traits showed consistent correlations between them. For instance, among the macroelements and macroelements with microelements, a highly significant relationship was detected between $\mathrm{MgC}$ and $\mathrm{KC}$, and $\mathrm{FeC}$ and $\mathrm{CaC}$, respectively. The correlations between PhyC and the metal concentrations were highly significant in the order of $\mathrm{ZnC}, \mathrm{CaC}$, and $\mathrm{FeC}$.

Table 3. $\mathrm{R}^{2}$ correlation coefficients with $\mathrm{p}$ values between nutrient concentration, phytic acid, and thousand grains weight.

\begin{tabular}{|c|c|c|c|c|c|c|c|}
\hline cv. Zhenis & TGW & GPC & $\mathrm{FeC}$ & $\mathrm{ZnC}$ & $\mathrm{CaC}$ & KC & $\mathrm{MgC}$ \\
\hline GPC, \% & 0.024 & & & & & & \\
\hline $\mathrm{FeC}(\mathrm{mg} / \mathrm{kg})$ & 0.002 & 0.000 & & & & & \\
\hline $\mathrm{ZnC}(\mathrm{mg} / \mathrm{kg})$ & $0.622^{* * *}$ & 0.017 & $0.34^{*}$ & & & & \\
\hline $\mathrm{CaC}(\mathrm{mg} / \mathrm{kg})$ & 0.011 & 0.000 & $0.98^{* * *}$ & 0.052 & & & \\
\hline $\mathrm{KC}(\mathrm{mg} / \mathrm{kg})$ & $0.908^{* * *}$ & 0.02 & 0.12 & $0.32^{*}$ & $0.042^{*}$ & & \\
\hline $\mathrm{MgC}(\mathrm{mg} / \mathrm{kg})$ & $0.606^{* * *}$ & 0.0125 & $0.44^{* *}$ & $0.48^{* *}$ & $0.297^{*}$ & $0.869^{* * *}$ & \\
\hline PhyC (mg/g) & $0.454^{* *}$ & 0.0128 & $0.504^{* *}$ & $0.972^{* * *}$ & $0.646^{* * *}$ & 0.175 & 0.004 \\
\hline \multicolumn{8}{|c|}{100 Gy-dosed lines } \\
\hline GPC, \% & 0.01 & & & & & & \\
\hline $\mathrm{FeC}(\mathrm{mg} / \mathrm{kg})$ & $0.081^{*}$ & 0.014 & & & & & \\
\hline $\mathrm{ZnC}(\mathrm{mg} / \mathrm{kg})$ & $0.084^{*}$ & 0.000 & $0.11^{* *}$ & & & & \\
\hline $\mathrm{CaC}(\mathrm{mg} / \mathrm{kg})$ & 0.005 & 0.025 & 0.045 & $0.063^{*}$ & & & \\
\hline $\mathrm{KC}(\mathrm{mg} / \mathrm{kg})$ & 0.028 & 0.009 & 0.009 & 0.006 & 0.048 & & \\
\hline $\mathrm{MgC}(\mathrm{mg} / \mathrm{kg})$ & 0.0037 & 0.022 & 0.022 & 0.000 & 0.011 & 0.019 & \\
\hline PhyC (mg/g) & $0.092^{* *}$ & 0.012 & $0.080^{*}$ & 0.043 & 0.021 & 0.022 & 0.000 \\
\hline \multicolumn{8}{|c|}{200 Gy-dosed lines } \\
\hline GPC, \% & 0.005 & & & & & & \\
\hline $\mathrm{FeC}(\mathrm{mg} / \mathrm{kg})$ & $0.220^{*}$ & 0.011 & & & & & \\
\hline
\end{tabular}




\begin{tabular}{llllllll}
$\mathrm{ZnC}(\mathrm{mg} / \mathrm{kg})$ & 0.009 & 0.012 & $0.35^{* *}$ & & & & \\
$\mathrm{CaC}(\mathrm{mg} / \mathrm{kg})$ & 0.03 & 0.014 & 0.036 & 0.004 & & & \\
$\mathrm{KC}(\mathrm{mg} / \mathrm{kg})$ & $0.225^{*}$ & $0.27^{* *}$ & $0.442^{*}$ & $0.28^{* *}$ & 0.000 & & \\
$\mathrm{MgC}(\mathrm{mg} / \mathrm{kg})$ & 0.037 & $0.164^{*}$ & 0.052 & 0.105 & $0.511^{* * *}$ & 0.052 & \\
$\mathrm{PhyC}(\mathrm{mg} / \mathrm{g})$ & $0.323^{* *}$ & $0.254^{*}$ & $0.273^{* *}$ & 0.027 & 0.011 & 0.175 & 0.13 \\
\hline
\end{tabular}

The lines were significantly different from the parent line. Each line was analyzed by three replicates. ${ }^{*}, * *$ and *** denote significance at the $0.05,0.01$, and 0.001 probability level, respectively.

Generally, the correlations between the investigated traits were found to be essentially lower than the $\mathrm{cv}$. Zhenis and $200 \mathrm{~Gy}$-derived lines, for the $100 \mathrm{~Gy}$-derived lines. There was a significant and positive association between $\mathrm{FeC}$ and $\mathrm{ZnC}\left(\mathrm{r}^{2}=0.11, p<0.01\right)$ (Table 3). As we revealed for the 100 Gy- and 200 Gy-derived lines, but not for the parent, there was a significant and positive association between FeC and TGW that was stronger in the $200 \mathrm{~Gy}$-derived lines. Among the macroelements and macroelements with microelements, the $200 \mathrm{~Gy}$-dosed lines showed significant relations of $\mathrm{MgC}$, unlike the parent and $100 \mathrm{~Gy}$-derived lines, with $\mathrm{CaC}$ and also with GPC. Another distinctive significant feature in the 200 Gy-dosed lines was the correlation between KC with GPC, $\mathrm{FeC}$, and $\mathrm{ZnC}$. A significant relation was also revealed between Phy and $\mathrm{FeC}$, and also GPC, but not with $\mathrm{ZnC}$.

The relations between Phy:nutrients molar rations and TGW and GPC were also analyzed (Table 4). In the parent $\mathrm{cv}$. Zhenis, there was only a significant relation between TGW and Phy:Zn. The 100 Gy- and 200 Gy-dosed lines presented significant correlations between TGW and Phy:Fe and Phy:K molar rations with their means more two times higher in $200 \mathrm{~Gy}$-dosed lines. These results indicate highly possible simultaneous improvement of both $\mathrm{Fe}$ and $\mathrm{Mg}$ bio-availabilities with the spring wheat productivity component.

Table 4. Association between phytic acid:nutrients molar rations and thousand grains weight and grain protein content for cv. Zhenis, spring wheat and advanced mutant lines (100 Gy-and $200 \mathrm{~Gy}$ - derived).

\section{Phy:Fe Phy:Zn Ca:Phy Phy:K Mg: Phy}

\begin{tabular}{|c|c|c|c|c|c|}
\hline \multicolumn{6}{|l|}{ cv. Zhenis } \\
\hline TGW, g & 0.007 & $0.759 * * *$ & 0.126 & 0.0065 & 0.067 \\
\hline GPC, $\%$ & 0.00 & 0.013 & 0.002 & 0.001 & 0.000 \\
\hline \multicolumn{6}{|c|}{100 Gy-derived lines } \\
\hline TGW, g & $0.086^{*}$ & 0.02 & 0.03 & $0.112 * *$ & 0.034 \\
\hline GPC, $\%$ & 0.025 & 0.005 & 0.00 & $0.133 * *$ & 0.004 \\
\hline \multicolumn{6}{|c|}{200 Gy-derived lines } \\
\hline TGW, g & $0.222 *$ & 0.033 & 0.003 & $0.292 * *$ & 0.14 \\
\hline GPC, $\%$ & 0.0012 & $0.141^{*}$ & 0.014 & 0.106 & $0.26^{*}$ \\
\hline
\end{tabular}

The lines were significantly different from the parent line. Each line was analyzed by three replicates. ${ }^{*} * *$, and

*** denote significance at the $0.05,0.01$, and 0.001 probability level, respectively. 
A significant relation between the Phy:K molar rations and GPC was only detected in the 100 Gy-treated mutant lines. In the case of the 200 Gy-treated lines, GPC showed a significant correlation with the Phy:Zn and Phy:Mg molar rations.

\subsection{Estimated Nutrients Bioavailability in Wheat Flours}

To estimate how the highest means of mineral concentrations from the parent and mutant lines provided the daily intake of $\mathrm{Fe}, \mathrm{Zn}, \mathrm{Mg}$, $\mathrm{Ca}$, and $\mathrm{K}$, we calculated the ratio of grain minerals concentration from $200 \mathrm{~g}$ flour consumption to the percentage of the recommended uptake (Table 5). These calculations were based on the statistics from the FAO [49], where the mean consumption of wheat flour is about $200 \mathrm{~g}$ per person per day, and on the values for the recommended intake for adults according to the DGE (German Nutrition Society) [50]. As indicated by these results, in the case of the parent, $\mathrm{Fe}, \mathrm{Zn}$, and $\mathrm{Mg}$ deficiencies were strongly manifested in decreasing order. The highest concentration of these minerals from the mutant lines that produced whole grain flour was revealed to provide 1.28-1.32 times more than that of the daily intake of $\mathrm{Fe}, \mathrm{Zn}$, and $\mathrm{Mg}$. The $\mathrm{K}$ concentration and particularly $\mathrm{Ca}$ in the grain of the parent and mutant lines supplied were 5.05-12.5 and 1.46-2.44 times higher, respectively, when compared to the required daily consumption of these minerals.

Table 5. Comparison of mineral concentration (mg/kg) in cv. Zhenis, $100 \mathrm{~Gy}$ - and $200 \mathrm{~Gy}$-derived lines with the recommended uptake and percentage of recommended uptake from flour consumption $200 \mathrm{~g} / \mathrm{person} /$ day (mg/day).

\begin{tabular}{|c|c|c|c|c|c|c|c|c|c|c|c|}
\hline $\begin{array}{l}\text { Min } \\
\text { eral } \\
\text { con } \\
\text { cent } \\
\text { rati } \\
\text { on } \\
(\mathrm{mg} \\
/ \mathrm{kg})\end{array}$ & \multicolumn{2}{|c|}{ Genotypes } & $\begin{array}{l}\text { Recomm } \\
\text { ended } \\
\text { uptake } \\
\text { of } \\
\text { minerals } \\
\text { (mg/day) } \\
\text { accordin } \\
\text { g to DCE }\end{array}$ & $\begin{array}{l}\text { Perce } \\
\text { ntage } \\
\text { of } \\
\text { reco } \\
\text { mme } \\
\text { nded } \\
\text { uptak } \\
\text { e } \\
\text { from } \\
\text { flour } \\
\text { consu } \\
\text { mptio } \\
\text { n and } \\
200 \\
\text { g/per } \\
\text { son/d } \\
\text { ay }\end{array}$ & \multicolumn{3}{|c|}{$\begin{array}{l}\text { mg minerals from } 200 \mathrm{~g} \\
\text { flour consumption } \\
\text { obtained } \\
\text { from max values of } \\
\text { genotype } \\
\mathrm{s}\end{array}$} & $\begin{array}{l}\text { Minerals } \\
\text { mg } \\
\text { from } \\
\text { percentage } \\
\text { of } \\
\text { recommen } \\
\text { ded } \\
\text { uptake }\end{array}$ & \multicolumn{3}{|c|}{$\begin{array}{l}\text { Ratio of grain } \\
\text { minerals } \\
\text { concentration from } \\
\text { percentage of } \\
\text { recommended } \\
\text { uptake }\end{array}$} \\
\hline & $\begin{array}{l}\mathrm{cv} . \\
\text { Zheni } \\
\mathrm{s}\end{array}$ & $\begin{array}{l}10 \\
0 \\
G\end{array}$ & & & $\begin{array}{l}\mathrm{cv} . \\
\text { Zheni } \\
\mathrm{s}\end{array}$ & $\begin{array}{l}100 \text { Gy- } \\
\text { dosed } \\
\text { lines }\end{array}$ & $\begin{array}{l}200 \text { Gy- } \\
\text { dosed } \\
\text { lines }\end{array}$ & & $\begin{array}{l}\text { cv. } \\
\text { Zhe } \\
\text { nis }\end{array}$ & $\begin{array}{l}10 \\
\text { Gy }\end{array}$ & $\begin{array}{l}200 \\
\text { Gy- }\end{array}$ \\
\hline
\end{tabular}


11 of 18

\begin{tabular}{|c|c|c|c|c|c|c|c|c|c|c|c|}
\hline & & $\begin{array}{l}\text { y- } \\
\text { do } \\
\text { se } \\
\text { d } \\
\text { lin } \\
\text { es }\end{array}$ & & & & & & & & $\begin{array}{l}\text { dosed } \\
\text { lines }\end{array}$ & $\begin{array}{l}\text { dosed } \\
\text { lines }\end{array}$ \\
\hline $\mathrm{Fe}$ & 31.30 & $\begin{array}{l}88 \\
.8 \\
3\end{array}$ & 10 & 76 & 6.26 & 17.77 & 17.81 & 13.50 & 0.35 & 1.32 & 1.32 \\
\hline $\mathrm{Zn}$ & 36.1 & $\begin{array}{l}89 \\
.6 \\
0\end{array}$ & 10 & 78 & 7.22 & 17.92 & 17.62 & 13.98 & 0.40 & 1.28 & 1.26 \\
\hline $\mathrm{Mg}$ & $\begin{array}{l}686.5 \\
3\end{array}$ & $\begin{array}{l}10 \\
83 \\
.3 \\
0\end{array}$ & 350 & 78 & $\begin{array}{l}137.3 \\
1\end{array}$ & 216.66 & 217.68 & 168.99 & 0.63 & 1.28 & 1.29 \\
\hline $\mathrm{Ca}$ & $\begin{array}{l}357.0 \\
7\end{array}$ & $\begin{array}{l}88 \\
3 . \\
0\end{array}$ & 1000 & 8 & 71.41 & 176.6 & 171.30 & 14.13 & 5.05 & 12.50 & 12.12 \\
\hline $\mathrm{K}$ & $\begin{array}{l}3173 . \\
33\end{array}$ & $\begin{array}{c}52 \\
84 \\
.2\end{array}$ & 2000 & 41 & $\begin{array}{l}634.6 \\
7\end{array}$ & 1056.84 & 1097.50 & 433.30 & 1.46 & 2.44 & 2.53 \\
\hline
\end{tabular}

\section{Discussion}

This study clearly showed the potential of spring wheat genetically stable advanced (M7) mutant lines which were derived the 100 Gy and 200 Gy irradiation exceptionally high concentrations of nutritionally important nutrients ( $\mathrm{Ca}, \mathrm{Mg}, \mathrm{K}, \mathrm{Fe}, \mathrm{Zn}$, and GPC) and their bioavailability (Tables 1 and 3). The variation was $172.3-883.0 \mathrm{mg} / \mathrm{kg}$ for $\mathrm{CaC} ; 472.9-1088 \mathrm{mg} / \mathrm{kg}$ for $\mathrm{MgC} ; 3145-5485 \mathrm{mg} / \mathrm{kg}$ for $\mathrm{KC}$; $31.1-89.0 \mathrm{mg} / \mathrm{kg}$ for $\mathrm{FeC}$; and $22.2-89.6 \mathrm{mg} / \mathrm{kg}$ for ZnC. Among investigated minerals, the greatest increase in their concentrations in the mutant lines when compared to the parent was found in $\mathrm{FeC}$, followed by $\mathrm{CaC}$ and $\mathrm{ZnC}$ with means of 2.66, 2,47, and 2.42, respectively. The 17 genotypes (54.8\%), all of the $100 \mathrm{~Gy}$-derived lines, had a significantly 6.5 to $7.6 \%$ higher GPC relative to the parent.

The concentrations of minerals in the wheat mutant lines exceeded those already reported for hexaploid wheat by 2.35-2.96-fold for FeC [17,18,51-54]. Although environmental factors can influence grain metal concentrations, in this work, all the mutant lines and the parent were grown under the same field conditions treated same, with no specific fertilizer supplementation or other inputs of these metals. The study that used 63 historical and modern wheat cultivars for the evaluation of grain yield and concentration of $\mathrm{Ca}, \mathrm{Cu}, \mathrm{Fe}, \mathrm{Zn}, \mathrm{Mg}$, $\mathrm{Mn}, \mathrm{P}$, and Se reported that over a long time, the concentrations of all minerals, except Ca, decreased, while grain yield increased [17,18]. Therefore the situations shows that a greater consumption of wheat bread from modern cultivars is required to achieve the same percentage of recommended dietary allowance levels contributed by other genetic resources or older cultivars with low yield. 
Micronutrient intake from wheat is essentially determined by the amount of their availability for human absorption. High micronutrient bioavailability can be achieved by the reduction of antinutritional agents, particularly Phy, considered to be the most important causative factor $[4,5,14]$. The main functions of Phy is as a phosphorus and energy store, and a source of cations and myoinositol as well as combating environmental issues related to seed PA-P could be improved by decreasing PhyC.

Breeding for low PAC is a reasonable objective to enhance nutrient bioavailability in grain. For the decline of PhyC, essential efforts have been made to mutagenize crops. Low phytate cereal mutants (lpa) have been reported using chemical and physical mutagenesis [30-32,33,55]. In wheat, the lpa mutant was isolated by chemical mutagenesis [32]. The lpa maize mutants have been used for the breeding of high inorganic phosphate (HIP) phenotypes [29]. At the same time, the lpa mutations found in several crops usually lead to pleiotropic effects on plant and seed performance such as reduced germination and emergence rate, lower seed filling, and susceptibility to stress [29]. Our experiments showed that low Phy wheat lines generated on cv. Zhenis and the $100 \mathrm{~Gy}$ and $200 \mathrm{~Gy}$ radiation did not differ when compared with the parent in seed viability, shoots and roots growth (data not shown).

The variation found for PhyC ranged from 1.17 to $2.66 \mathrm{mg} / \mathrm{g}$ (2.3-fold variation) in all of the mutant lines (Table 1). There were significant differences between the $100 \mathrm{~Gy}$ - and $200 \mathrm{~Gy}$-derived mutant lines (Table 2). The lowest PhyC presented in the 100 Gy-dosed lines and numbed by (24(7) was more than two times lower, relative to that of the parent. It is an interesting fact that searching for low Phy lines among the M7 mutant lines generated by the $100 \mathrm{~Gy}$ on a genetic background of cv. Eritrospermum-35, allowed us to identify the lowest PhyC, which was lower relative to the parent by 3.5 times [57].

Studies of natural wheat variation revealed the huge difference for PhyC. Similar PhyC to the means of the current study were reported in Liu et al. (2017) [58]. Higher PhyC was found in 93 wheat genotypes (5.9 to $20.1 \mathrm{mg} / \mathrm{g}$ ) [59], in modern varieties (12.5 to $34.2 \mathrm{mg} / \mathrm{g}$ ) [60], Indian bread wheat (23.9 mg/g) [61], from 6.7 to $10.5 \mathrm{mg} / \mathrm{g}$ [44], from 7.65 to $8.8 \mathrm{mg} / \mathrm{g}$ [62], and ranged from 7 to $13 \mathrm{mg} / \mathrm{g}$ depending on $\mathrm{Zn}$ fertilization [63]. The highest PhyC was also reported for whole-wheat flour (44.91 $\mathrm{mg} / \mathrm{g}$ ) [64] and Spanish wheat (24.6-45.4 mg/g) [65]. Possible explanations for the inconsistent finding might be to do with the methodology of PA determination also indicared by Gibson et 1., 2010 [66]. that the selection of the most appropriate method for the PA analysis is critical.

The potential bioavailability of the nutrients for human consumption is estimated by the Phy:micronutrients molar ratios or vice versa for the microelements. In general, low molar ratio means high mineral bioavailability and the same conversely. In the current study, significant variability for the Ca:Phy, Mg:Phy, Phy:K, Phy:Fe, and Phy:Zn molar ratios between the parent and mutant lines was detected (Table 1). Among them, the most pronounced variation when compared to the others were for Ca:Phy (more than 7-fold) and for Phy:Zn (around 7-fold) in the 100 Gy-dosed mutant lines. A high_variation for Phy:Fe (1.40-5.32) with its mean of about a 4-fold difference was also detected. To significantly increase Fe and Zn absorption Phy:Fe molar ratios was estimated at $<1$ or preferably $<0.4$ [67] and for the Phy:Zn molar ratio, $<5$ was considered as high Zn bioavailability, corresponding to approximately $50 \%$ of the total Zn [68]. A similar study with a Phy:Fe range of 1.963.86 in 12 bread wheat varieties was reported in [69]. There were higher Phy:Fe molar ratios in the literature such as means of around 12 in two bread wheat cultivars [70], 10-12 in wheat whole flour 
[57], and of 15.5-31.3 in a set of nine bread wheat varieties [71]. For the Phy:Zn molar ratio, means of 23.9-41.4 in 65 bread wheat varieties of Pakistan [72], and ones of 29-178 in bread wheat [73] have been reported. In human studies, the molar ratio $[\mathrm{Ca}][\mathrm{Phy}] /[\mathrm{Zn}]$ is a better forecaster of $\mathrm{Zn}$ bioavailability as Ca strengthens the effect of Phy on $\mathrm{Zn}$ absorption due to the existence of kinetic synergism between the $\mathrm{Ca}$ and $\mathrm{Zn}$ ions resulting in the formation of a more insoluble Ca:Zn:Phy complex when compared to the Phy complexes formed by either alone. A [Ca][Phy]/[Zn] molar ratio greater than $0.5 \mathrm{~mol} / \mathrm{kg}$ may reduce the Zn bioavailability [74]. The current study showed considerable variation for this character (0.21-3.01 and 0.30-3.32) in the $100 \mathrm{~Gy}$ - and $200 \mathrm{~Gy}$-derived mutant lines, respectively (Table 1). This means that there was a 11.0-14.3-fold variation in a set of lines and the ones with the lowest values for $[\mathrm{Ca}][\mathrm{Phy}] /[\mathrm{Zn}]$ fall in the category of high $\mathrm{Zn}$ bioavailability according to [74].

\section{Conclusions}

In our study, to search for biofortification by nutrients ( $\mathrm{Ca}, \mathrm{Mg}, \mathrm{K}, \mathrm{Fe}, \mathrm{Zn}$, and GPC) and high bioavailability, spring wheat new genetically stable $\left(M_{7}\right)$ mutant lines which were 100 and $200 \mathrm{~Gy}$ treatments and the parent $\mathrm{cv}$. Zhenis were investigated. The results indicate that these mutant resources of spring wheat can substantially increase the metals bioavailability and health impact of wheat end products. There was only a correlation between TKW and concentrations of Fe in the mutant lines; in addition, such relations were observed for Ca and Phy, and a significant correlation existed between GPC and the concentrations of $\mathrm{K}, \mathrm{Mg}$, and Phy. Thus, a greater consumption of whole wheat bread from new mutant lines could contribute to achieving the percentage of recommended dietary allowance levels. Using the abundant variation present in wheat mutant lines, it should be possible to improve mineral concentrations and their bioavailability in modern cultivars without negatively affecting yield.

Author Contributions: S.K., F.S., and G.Zh. conceived and designed the experiments; G.D., A.A., N.O., S.T. .and G.E. performed the experiments; S.K., F.S., and S.A. analyzed the data and wrote the paper.

Acknowledgments: This research was funded by the Ministry of Education and Sciences of the Republic of Kazakhstan for funding the project 074/GF "The creation and study of mutant genotypes of wheat for identifying valuable breeding forms and new alleles of genes controlling key adaptive properties" and AP05131881 "Development of integrated approaches for biofortification, high bioavailability of the most important micronutrients of spring wheat and health". The authors are thankful to the International Atomic Energy Agency (IAEA, Austria) for providing technical and financial assistance under National TC project KAZ/5003, "Increasing Micronutrient Content and Bioavailability in Wheat Germplasm by Means of an Integrated Approach".

Conflicts of Interest: The authors declare no conflict of interest. The founding sponsors had no role in the design of the study; in the collection, analyses, or interpretation of data; in the writing of the manuscript, and in the decision to publish the results.

\section{References}

1. FAO, 2014. FAOSTAT. www.fao.org.

2. Global nutrition report. 2016. From promise to impact. Ending malnutrition by 2030.

3. Nutrition for health and development: progress report (NHD).A global agenda for combating malnutrition 
4. Welch, R.M.; Graham, R.D. Breeding for micronutrients in staple food crops from a human nutrition perspective. J. Exp Bot. 2004, 55, 353-364, DOI: 10.1093/jxb/erh064

5. Lim, K.; Riddell, L.; Nowson, C.; Booth, A.; Szymlek-Gay, E. Iron and zinc nutrition in the economicallydeveloped world: A Review. Nutrients. 2013, 5, 3184-3211, DOI:10.3390/nu5083184.

6. Black, R.; Victora, C.G.; Walker, S.P.; Bhutta, Z.A.; Christian, P.; de Onis, M.; Ezzati, M.; GranthamMcGregor, S.; Katz, J.; Martorell, R.; Uauy, R. Maternal and childnutrition study group. Maternal and child undernutrition and overweight inlow-income and middle-income countries. Lancet. 2013, 382, 427451, DOI:10.1016/S0140-6736(13)60937-X. Epub 2013 Jun 6.

7. Maret, W.; Sandstead, H.H. Zinc requirements and the risks and benefits of zinc supplementation. J. Trace Elem. Med.Biol. 2006. 20, 3-18, DOI:10.1016/j.jtemb.2006.01.006. PMID16632171.

8. Kordas, K.; Stoltzfus, R,J. New evidence of iron and zinc interplay at the enterocyte and neural tissues. J. Nutr. 2004, 134, 1295-1298, DOI:10.1093/jn/134.6.1295.

9. Nair, K.M.; Brahmam, G.N.; Radhika, M.S.; Dripta, R.C.; Ravinder, P.; Balakrishna, N.; Chen, Z.; Hawthorne, K.M.; Abrams, S.A. Inclusion of guava enhances non-heme iron bioavailability but not fractional zinc absorption from a rice-based meal in adolescents. J. Nutr.2013, 143, 852-858, DOI: 10.3945/jn.112.171702.

10. Frossard E.; Bucher, M.; Machler F.; Hirrel, R. Potential for increasing the content and bioavailability of Fe, Zn and Ca in plants for human nutrition. J. the Science of Food and Agriculture. 2000, 80, 861 - 879, DOI: 10.1002/(SICI)1097-0010(20000515)80:7<861:AID-JSFA601>3.0.CO;2-P.

11. Welch, R,M.; Graham, R,D. Breeding crops for enhanced micronutrient content. Plant Soil, 2002, 245, 205-214, DOI: https://doi.org/10.1023/A:1020668100330.

12. Rude, R.K.; Gruber, H.E. Magnesium deficiency and osteoporosis: animal and human observations. J Nutr. Biochem. 2004, 15, 710-716, DOI: 10.1016/j.jnutbio.2004.08.001.

13. Thacher TD, Fischer PR, Strand MA, Pettifor JM. Nutritional ricks around the world: causes and future directions. Ann. Trop. Paediatr. 2006, 26, 1-16.

14. White, P.J.; Broadley, M.R. Biofortification of crops with seven mineral elements often lacking in human diets - iron, zinc, copper, calcium, magnesium, selenium and iodine. New Phytol. 2009, 182, 49-84, DOI: 10.1111/j.1469-8137.2008.02738.x.

15. FAOSTAT 2008; http://faostat.fao.org;

16. Godfray, H, C.; Beddington J, J, R.; Crute, I.R.; Haddad, L.; Lawrence, D.; Muir, J.F.; Pretty, J.; Robinson, S.; Thomas, S.M.; Toulmin, C. Food security: the challenge of feeding 9 billion people. Sci. 2010, 327, 812-818, DOI: $10.1126 /$ science.1185383.

17. Murphy, K,M.; Reeves, P, G.; Jones, S,S. Relationship between yield and mineral nutrient concentrationsin historical and modern spring wheat cultivars. Euphytica, 2008, 163, 381-390, DOI: 10.1007/s10681-008-9681-x.

18. Fan, M. S., Zhaoa, F. J., Fairweather-Tait, S.J., Poulton, P. R., Dunham, S. J.;McGrath, S. P. Evidence of decreasing mineral density in wheat grain over the last160 years. J. Trace Elem. Med. Biol. 2008, 22: 315324 , DOI: $10.1016 /$ j.jtemb.2008.07.002.

19. Morgounov, A.; Belan I.; ,Zelenskiy, Y.; Roseeva, L.; To“mo“sko“zi, S.;Be'ke’s, F.; Abugalieva, A.; Cakmak, I., Vargas, M.; Crossa, J. Historical changes in grain yield and quality of springwheat varieties cultivated in Siberia from 1900 to 2010. Can. J. Plant Sci. 2013, 93, 425-433, DOI: 10.4141/CJPS2012-091 
20. Myers, S.S.; Zanobetti, A.; Kloog, I.; Huybers, P.; Leakey, A.; Bloom, A.J.; ; Carlisle, E.; Dietterich, L.H.; Fitzgerald, G.; Hasegawa, T.; et al. Increasing $\mathrm{CO}_{2}$ threatens human nutrition, Nature, 2014, 510, 139-142 , DOI: 10.1038/nature13179.

21. Zhao, F.J.; Su, Y.H.; Dunhama, S.J.; Rakszegi, M.; Bedo, Z.; McGrath, S.P.; Shewry, P.R. Variation in mineral micronutrient concentrations in grain of wheat lines of diverse origin. J. Cereal Sci. 2009, 49. 290295, DOI: 10.1016/j.jcs.2008.11.007.

22. Borrill, P.; Connorton, J.M.; Balk, J.; Miller, A.J.; Sanders, D.; Uauy, C. Biofortification of wheat grain with iron and zinc: integrating novel genomic resources and knowledge from model crops. Front Plant Sci., 2014, 5, 1-8, DOI: 10.3389/fpls.2014.00053

23. Bouis, H. E.; Saltzman, A. Improving nutrition through biofortification: A review of evidence from HarvestPlus, 2003 through 2016. Global Food Security, 2017, 12, 49-58. DOI: org/10.1016/j.gfs.2017.01.009.

24. Rosado, J.L.; Hambidge, K.M.; Miller, L.V.; Garcia, O.P.; Westcott, J.; Gonzalez, K.; Conde, J.; Hotz, C.; Pfeiffer,W.; Ortizmonasterio, I. The quantity of zinc absorbed from wheat in adult women is enhanced by biofortification. J. Nutr. 2009, 139, 1920-1925, DOI: 10.3945/jn.109.107755.

25. Schlemmer, U.; Frølich, W.; Prieto, R. M.; Grases, F. Phytate in foods and significance for humans: Food sources, intake, processing, bioavailability, protective role and analysis Mol. Nutr. Food Res. 2009, 53, S330 -S375, DOI: 10.1002/mnfr.200900099.

26. Bouis, H.E.; Welch, R.M. Biofortification-A Sustainable Agricultural Strategy for Reducing Micronutrient Malnutrition in the Global South. Crop Science. 2010, 50, S21-S32, DOI: 0.2135/cropsci2009.09.0531.

27. Lönnerdal, B. Phytic acid-trace element (Zn, Cu, Mn) interactions. Int J Food Sci Technol. 2002, 37, 749-758, DOI: https://doi.org/10.1046/j.1365-2621.2002.00640.x.

28. Oberleas D. The role of phytate in zinc bioavailability and homeostasis. In: Inglett GE (Ed.), Nutritional bioavailability of zinc. American Chemical Society, Washington DC, 1983; 145-158.

29. Raboy, V.; Gerbasi P.F.; Young K.A.; Stoneberg, S.D.; Pickett S.G.; Bauman A.T.; Murthy, P.P.N.; Sheridan, W.F.; Ert, D.S. Origin and seed phenotype of maize low phytic acid 1-1 and low phytic acid 2-1. Plant Physiol, 2000, 124, 355-368, DOI: https://doi.org/10.1104/pp.124.1.355.

30. Liu, Q.L.; Xu, X.H.; Ren, X.L.; Fu, H.W.; Wu, D.X.; Shu, Q.Y. Generation and characterization of low phytic acid germplasm in rice (Oryza sativa L.). Theor. Appl. Genet, 2007, 114, 803-814, DOI: 10.1007/s00122-0060478-9.

31. Badone, F,C.; Amelotti, M.; Cassani, E.; Pilu, R. Study of low phytic acid1-7 (lpa1-7), a New ZmMRP4 mutation in maize. J Heredity. 2012, 103, 598-605, DOI: 10.1093/jhered/ess014.

32. Guttieri MJ, Bowen D, Dorsch JA, Raboy V, Souza E, Identification and characterization of a low phytic acid wheat. Crop Sci. 2004, 44, 418-24, DOI: 10.2135/cropsci2004.4180.

33. Pilu, R.; Panzeri, D.; Gavazzi, G.; Rasmussen S.K.; Consonni, G.; Nielsen, E. Phenotypic, genetic and molecular characterization of a maize low phytic acid mutant (lpa241). TheorAppl Genet. 2003, 107, 980987, DOI: 10.1007/s00122-003-1316-y.

34. Akfirat FS, Uncuoglu AA, Genetic diversity of winter wheat (Triticumaestivum L.) revealed by SSR markers. Biochem Genet. 2013, 51, :223-229, DOI: 10.1007/s10528-012-9557-6.

35. (http://mvgs.iaea.org/).

36. Parry, M.A., Madgwick PJ, Bayon, C., Tearall, K, Hernandez-Lopez, A., Baudo, M., Rakszegi M., Hamada W, Al-Yassin A, Ouabbou, H., Labhilili M., Phillips, A.L. Mutation discovery for crop improvement. J Exp. Bot. 2009, 60, 2817-2825, DOI: 10.1186/1471-2229-12-205. 
37. Tomlekova, N. B., M. I. Kozgar, and M. R. Wani, eds. 2014. Mutagenesis: Exploring genetic diversity of crops. Wageningen, The Netherlands: Academic Publishers.

38. Volpe, S.L. Magnesium. In: Erdman J.W.; Macdonald I.A.; Zeisel S.H. eds. Present Knowledge in Nutrition. $10^{\text {th }}$ ed. Ames, Iowa; John Wiley \& Sons, 2012:459-74, DOI: 10.1023/A:1016022730880.

39. Stone, M.S., Martyn, L., Weaver, C.M. Potassium intake, bioavailability, hypertension, and glucose control. Nutrients. 2016, 8, 444 , DOI: 10.3390/nu8070444.

40. Committee to review dietary reference intakes for vitamin D and calcium, food and nutrition board, Institute of medicine. Dietary reference intakes for calcium and vitamin D. Washington, DC: National Academy Press, 2011, DOI: 10.17226/13050.

41. Dai, Q.; Motley, S.S.; Smith, J.A.; Concepcion, R. Jr.; Barocas, D.; Byerly, S.; Fowke, J.H. Blood magnesium, and the interaction with calcium, on the Risk of high-grade prostate cancer. PLOS one 2011, DOI: org/10.1371/journal.pone.0018237.

42. Rosanoff, A. Rising Ca:Mg intake ratio from food in USA Adults: a concern? Magnesium Res, 2010, 23, S181-93, DOI: 10.1684/mrh.2010.0221.

43. Greiner, R.; Konietzny, U.; Jany K-D. Phytate - an undesirable constituent of plant-based foods? J. für Ernährungsmedizin, 2006, 8, 18-28.

44. Sandström, B.; Cederblad A, Stenquist, B.; Andersson, H. Effect of inositol hexaphosphate on retention of zinc and calcium from the human colon. Eur J Clin Nutr. 1990, 44, 705-708.

45. Lopez, H.W.; Leenhardt, F.; Coudray, C.; Remesy, C. Minerals and phytic acid interactions: is it a real problem for human nutrition? Int J Food Sci Technol. 2002, 37, 727-739, DOI: 10.1046/j.13652621.2002.00618.x.

46. Balyan, H. S.; Gupta, P.K.; Kumar, S.; Dhariwa, R.; Jaiswa, V.; Tyagi, S.; Agarwal, P. et al. . Genetic improvement of grain protein content and other health-related constituents of wheat grain. Plant Breed. 2013, 132, 446-57, DOI: org/10.1111/pbr.12047.

47. Kenzhebayeva, S.S.; Doktyrbay, G.; Capstaff, N.M.; Sarsu, F.; Omirbekova, N., Zh.; Eilam, T.; Tashenev, D.K.; Miller A.J. Searching a spring wheat mutation resource for correlations between yield, grain size, and quality parameters. Crop Improv. 2017, 31, 208-228, DOI: 10.1080/15427528.2016.1276990.

48. Dai, F.; Wang, J.M.; Zhang, S.H.; Xu, Z.Z.; Zhang, G.P. Genotypic and environmental variation in phytic acid content and its relation to protein content and malt quality in barley. Food Chem. 2007,105, 606-611, DOI:10.1016/j.foodchem.2007.04.019.

49. FAO (Food and Agriculture Organization). Food supply; Available online: http://faostat.fao.org/ site/609/DesktopDefault.aspx?PageID=609.(accessed on 09 December 2005).

50. DGE (German Nutrition Society). Referenzwerte fur die Nährstoffzufuhr, 1. Auflage; Hrs. DGE, ÖGE, SGE und SVE, 1st ed.; Umschau/Braus: Frankfurt, Germany, 2001.

51. Ryan, M.; Derrick, J.; Dann, P. Grain mineral concentrations and yield of wheat grown under organic and conventional management. J. Sci. Food Agri. 2004, 84, 207-216, DOI: org/10.1002/jsfa.1634

52. Zhao, F,J.; Su, Y,H.; Dunham, S,J.; Rakszegi, M.; Bedo, Z.; McGrath,S, P.; Shewry, P.R. Variation in mineral micronutrient concentrations in grain of wheat lines of diverse origin. J. Cereal Sci. 2009, 49, 290-295, DOI:10.1016/j.jcs.2008.11.007.

53. Kirchmann, H.; Mattsson, L.; Eriksson, J. Trace element concentration in wheat grain: Results from the Swedish long-term soil fertility experiments and national monitoring program. Environ. Geochem. Health 2009, 31, 561-571. 
54. Hussain A.; Larsson, H.; Kuktaite, R.; Johansson, E. Mineral composition of organically grown wheat genotypes: contribution to daily minerals intake. Int. J. Environ. Res. Public Health. 2010, 7, 3442-3456; DOI:10.3390/ijerph7093442

55. Liu, Q.L., X.H. Xu, X.L. Ren, H.W. Fu and D.X. Wu, et al. Generation and characterization of low phytic acid germplasm in rice (Oryza sativa L.). Theor. Appl. Genet., 2007. 114, 803-814.

56. Sparvoli, F.; Cominelli, E. Seed biofortification and phytic acid reduction: a conflict of interest for the plant? Plants 2015, 4, 728-755, DOI:10.3390/plants4040728.

57. Kenzhebayeva, S.; Abekova, A.; Zhang, G.; Zharassova, D.; Dai, F.; Omirbekova, N.; Tashenev, D. New spring wheat mutation resources with improved grain quality, metals bioavailability and yield components. Am. J. Agricult. Biol. Sci. 2017, 12, 167-181, DOI: 10.3844/ajabssp.2017.167.181.

58. Liu, D.; Liu, Y.; Zhang, W.; Chen, X.; Zou, Ch. Agronomic approach of zinc biofortification can increase zinc bioavailability in wheat flour and thereby reduce zinc deficiency in humans, Nutrients, 2017, 9, 465. DOI:10.3390/nu9050465

59. Gupta, R.K.; Gangoliya, S.S.; Singh, N.K. Screening and characterization of wheat germplasms for phytic acid and iron content. J Agr Sci. Tech. 2015, 17, 747-756.

60. Ahmad, I.; Mohammad, F.; Zeb, A.; Noorka, R.I.; Farhatullah, Jadoon, S.A. Determination and inheritance of phytic acid as marker in diverse genetic group of bread wheat. Am J of Mol. Biol. 2013, 3, 158-164, DOI: org/10.4236/ajmb.2013.33021.

61. Yenagi, S.N.; Basarkar, P.W. Antioxidant contents of whole grain cereals of North Karnataka. Karnataka J Agric Sci. 2008, 21, 602-603.

62. Tavajjoh, M.; Yasrebi, J.; Karimian, N.; Olama, V. Phytic acid concentration and phytic acid: Zinc molar ratio in wheat cultivars and bread flours, Fars Province, Iran. J Agr. Sci Tech. 2011, 13, 743-755.

63. Erdal, I.; Yilmaz, A.; Taban, S.; Eker, S.; Torun, B.; Carmak, I. Phytic acid and phosphorus concentrations in seeds of wheat cultivars grown with and without zinc fertilization. J Plant Nutr. 2002, 25, 113-127, DOI:org/10.1081/PLN-100108784.

64. Frontela C, Ros G, Martínez C, Phytic acid content and "in vitro" iron, calcium and zinc bioavailability in bakery products: The effect of processing. J Cereal Sci. 2011, 54, 173-179, DOI:1 0.1016/j.jcs.2011.02.015.

65. García-Estepa, R.M.; Guerra-Hernández, E.; García-Villanova, B. Phytic acid content in milled cereal products and breads. Food Res Int. 1999, 32, 217-221.

66. Gibson, R.S.; Bailey, K.B.; Gibbs, M.; Ferguson, E.L. A review of phytate, iron, zinc, and calcium concentrations in plant-based complementary foods used in low-income countries and implications for bioavailability. Food Nutr Bull. 2010, 31(2S), 134-146, DOI: 10.1177/15648265100312S206.

67. Hurrell, R., Egli, I. Iron bioavailability and dietary reference values. The Am. J Clin. Nutr., 2010, 91, 1461S1467S, DOI: 10.3945/ajcn.2010.28674F.

68. Gibson, R.S. Zinc: the missing link in combating micronutrient malnutrition in developing countries. Proc. Nutr. Soc. 2006, 65, 51-60, DOI: org/10.1079/PNS2005474.

69. Akhter, S., Saeed, A., Irfan, M., Malik, K.A. In vitro dephytinization and bioavailability of essential minerals in several wheat varieties. J. Cereal Sci. 2012, 56, 741-746.

70. Eagling, T., Wawer, A. A., Shewry, P. R., Zhao, F., Fairweathertait, S.J. Iron bioavailability in two commercial cultivars of wheat: Comparison between whole grain and white flour and the effects of nicotianamine and 20-deoxymugineic acid on iron uptake into Caco - 2 cells. J Agric. Food Chem., 2014, 62, 10320-10325, DOI: 10.1021/jf5026295. 
71. Salunke, R., Rawat, N., Neelam, K., Tiwari, V. K., Randhawa, G. S., Dhaliwal, H. S., Roy, P. Effect of grain hardness on bioavailability of iron in wheat as determined using the coupled invitro digestion/Caco-2 model. LWT - J Food Sci. Tech. 2014, 59, 433-438, DOI: 10.1016/j.1wt.2014.04.031.

72. Hussain, S., Maqsood, M. A., Miller, L.V. Bioavailable zinc in grains of bread wheat varieties of Pakistan. Cereal Res. Commun. 2012, 40, 62-73, DOI: 10.1556/CRC.2011.003.

73. Erdal, I., Yilmaz, A., Taban, S., Eker, S., Torun, B., Cakmak, I. Phytic acid and phosphorus concentrations in seeds of wheat cultivars grown with and without zinc fertilization. J Plant Nutr., 2002, 25, 113-127, DOI: org/10.1081/PLN-100108784.

74. Davis, N.T.; Warrington, S. The phytic acid, mineral, trace element, protein and moisture content of UK Asian immigrant foods. Hum. Nutr. Appl. Nutr. 1986, 40A, 49-59. DOI: 10.11648/j.ijnfs.20140304.18. 